\title{
10 Pursuing gender equality through the courts
}

\author{
The role of South Africa's women judges
}

\author{
Penelope Andrews
}

\section{Introduction}

This chapter will focus on the contribution of female judges to the transformation of the judiciary in South Africa and specifically the pursuit of gender equality. It is a limited project that will explore the impacts of women judges on constitutional jurisprudence and how the influence of women judges has interacted with the broader transformation of the judicial and political system in South Africa after apartheid. ${ }^{1}$ In examining the impact of women judges on constitutional jurisprudence with respect to gender equality, I explore whether women judges have, in their judgments, conscripted and interpreted the constitution to highlight and guarantee its transformative potential and possibilities.

The focus of my research project is partial, since it is based on a small number of judgments of the Constitutional Court, the highest court in South Africa. The very nature of the work of the Constitutional Court, the venue of last judicial resort, renders it an arcane institution vis-à-vis the rest of the judicial system. It was only established in 1995 in the wake of democracy and therefore occupies a rarefied place in the court structure. Most people in South Africa experience justice, or at least have their legal disputes adjudicated, in the lower courts, especially the Magistrates' Courts, as well as Indigenous courts. Since the decisions of these courts are not published, a study of their decisions would require resources, time, and particularized expertise-which is outside the scope of this chapter. A study of judgments of the Constitutional Court, however, does provide a mechanism to investigate constitutional interpretation early on in the South African democratic project. These judgments do provide an indication of the jurisprudential direction of the country—and how lower courts might in turn implement and interpret the constitution.

\section{A curtain-raiser}

Although their cohabitation was never formalized, they had lived together for over two decades as a married couple and were perceived as such by the outside world. One of the few legal avenues available to her to claim some access to the property they had accumulated over the course of their relationship was to 
prove that a universal partnership existed between them. The law provided limited relief by analogizing the universal partnership rules for commercial transactions to the private situation of cohabitation. Several criteria needed to be satisfied, and an important factor for the court in its deliberations was her tangible contribution as well as the notion that the partnership existed for profit. He claimed that no universal partnership existed and that her claim should be thrown out for failure to demonstrate the evidence needed to establish such a partnership.

The judge, who had researched and written extensively on women's rights and gender equality, considered both the tangible (monetary) resources brought to the partnership by the plaintiff and her intangible (non-monetary) contributions of domestic labor, care, and nurturing of the family. The couple had no children, but she had shared child-caring duties with him when his children from a previous marriage stayed periodically. The judge was familiar with the research that demonstrated how women historically had contributed to the household with unpaid labor-and how such labor was often not included in monetary settlements at the dissolution of a long-term relationship. The judge concluded that in fact, the plaintiff had shown sufficient evidence to establish a universal partnership, which permitted the plaintiff to survive a motion to dismiss her claim.

Could an argument be made that without these insights of a female judge, many women in South Africa would be bereft of an equitable distribution of property if they happen to have cohabited with a man for a considerable period without entering into a marriage or concluding a written contract? And would these insights be restricted to only female judges, who are assumed to be more "feminist" in their worldview than men? Coontz and others have suggested that a male judge may not express the insights highlighted because of the discrete experiences of women (Coontz, 2000; Wilson, 1990). No doubt, some male judges do bring an empathetic gendered perspective to their judgments, as I highlight later, but because of the lingering sexist attitudes and lived experiences of male and female judges in contemporary South Africa, the philosophical default for female judges may, on average, lean more contextually, and therefore more empathetically, toward the experience of female litigants. ${ }^{2}$

This minor example and the questions raised here to go to the heart of the discussion of why it is important that women judges be appointed and what women judges add to the bench, as well as the development of jurisprudence that speaks to the lived realities of women. Are their perspectives different, and are women judges more committed to an "ethic of care" (Gilligan 1982)? Is there a feminist judicial methodology? These are in many ways hackneyed questions that form part of the wider conversation regarding the feminization of the legal profession and the increasing presence of larger numbers of women in law schools and in the legal profession (Schultz \& Shaw, 2013; Norgren, 2018; Li et al., 2020). These questions have been part of an ongoing discussion among scholars, legal practitioners, and feminist activists for some time and have generated substantial research questions and analyses. What the research so far has demonstrated is the importance of a diverse judiciary for a range of reasons, including legitimacy, 
representation, competence, cultural competence, and empathy (Mossman, 2005; Hunter, 2008; Dixon, 2010; Durojaye \& Oluduro, 2016; Coontz, 2000).

In late 2018, I had the opportunity to serve as an acting judge of the North Gauteng High Court in Pretoria, a court of first instance as well as an appeal court. I presided over a range of cases: criminal appeals, civil trials, motion court, and admission of attorneys and advocates. The decision regarding universal partnerships mentioned earlier was one of the judgments that I delivered during the course of my term. As a longstanding law professor, the judicial experience was probably the most exhilarating and challenging of my career, engaging with the law from a hitherto unfamiliar vantage point. It helped me to consider up close some questions that I had raised before in relation to the judiciary, namely, how one's racial and gender identity impacts upon our decisions, as well as how we are perceived by lawyers who appear before us and the litigants that they represent (Andrews 2010) The experience confirmed my scholarly insights about how women and people of color (previously excluded from the judiciary) may be particularly attuned to a range of non-legal factors that impact the legal controversies that they adjudicate. The experience also confirmed for me the challenges that female judges, as voices of authority in the courtroom, continue to confront in the face of the male bias in the law (Dawuni \& Kuenyehia, 2018). As a former Judge-President of the Supreme Court of Appeal noted, "the advent of the liberating and empowering provisions of the constitution did not act, as might have been expected like the flick of an attitudinal switch." ${ }^{3}$

The question of whether women judges make a difference remains relevant, with different conclusions reached by different studies (Dawuni \& Bauer, 2016; Irving, 2017). In this chapter, I put that question to the test by investigating the contribution of South Africa's Constitutional Court judges, through their written judgments, to the pursuit of constitutional rights that reinforce gender equality. I have chosen to focus only on the Constitutional Court judges, since that court is the apex court in the country.

\section{Historical exclusion of women judges in South Africa}

The first woman to practice law in South Africa was only admitted in 1923, and up until the 1980s, the number of female legal practitioners, particularly black female practitioners, was very small. Colonialism and apartheid excluded black South Africans, male and female, from serving as judges on the High Courts, although black males, and to a lesser extent black females, served as magistrates in the lower courts. Gender discrimination excluded white women from serving as judges, although some managed to be appointed as magistrates (Masengu 2016, 2019).

Since 1994, with the adoption of a new constitution and the establishment of a democracy in South Africa, women have been appointed as judges. Their appointment in the past two decades raises many questions that go beyond the need for greater numbers and greater gender representation. As I have written elsewhere, consideration of racial and gender diversity, and to a lesser extent 
disability and sexual orientation diversity, has propelled the transformation of the judiciary in South Africa (Andrews 2008). This consideration is underpinned by the assumption, both stated and unstated, that a majority white and male judiciary is unable to serve and deliver justice to a majority black and female population. The project of constitutional democracy is contingent on a bench that reflects the racial and gender diversity of the society (Andrews 2010).

A recognition of and the reflection of diversity generate a further set of considerations as they pertain to women judges. In addition to the questions raised earlier, the issue of women's judicial authority and its interface with implicit bias is pertinent. So too are the notions of judicial neutrality and objectivity and their intersection with the subjective perspectives that women may bring, which are based on women's discrete experiences, particularly in the workplace. Some of these issues have been systematically addressed in the research in other jurisdictions as well as in various research projects globally (Mossman, 2005; Hunter, 2008; Dawuni, 2016; Dixon, 2010; Banks, 2017; Graycar, 2009; Coontz, 2000). A few comprehensive volumes have recently been published that have highlighted and analyzed the key questions relating to the role of women judges globally, focusing on the history of women in the judiciary; women serving on international tribunals; quotas, diversity, and representation; judicial training; judicial selection processes; the career paths of women judges; the difference in perspective between female and male judges; feminist adjudication; and women's place and impact in the judiciary (Schultz \& Shaw, 2013; Kenney, 2013; Hunter et al., 2010; Dawuni \& Bauer, 2016; Stanchi et al., 2016; Helen Irving, 2017; Dawuni \& Kuenyehia, 2018).

These questions are increasingly being addressed by scholars in South Africa and beyond. A range of feminist scholars have explored judicial transformation in South Africa, including the obstacles facing females for appointment to the judiciary, especially the pervasive discrimination against women in the legal profession and the wider society, the legal and political context of the judicial appointments process, and the impact of female judges on the bench and on constitutional jurisprudence (Masengu, 2016; Albertyn \& Bonthuys, 2016; Bauer \& Dawuni, 2016; Cowan, 2006; Phooko \& Radebe, 2016).

A perennial concern of research of this kind relates to gender essentialism, the notion of conflating women judges with feminist judges. The research, however, suggests that despite concerns of gender essentialism, there are concrete examples to demonstrate that women judges in fact make a difference (Wilson, 1990; Malleson, 2003; Coontz, 2000). But the difference is located in experience and not biology, with judges bringing not just legal knowledge and skill but also a "set of values, experiences and assumptions that are thoroughly embedded." ${ }^{4}$

\section{Transformation of the legal and judicial system}

Since 1994, the legal system in South Africa has moved from one premised on racism, sexism, and authoritarianism to one that strives to provide human rights for all South Africans; from a culture of authoritarianism to a culture of justification 
(Mureinik, 1994). Most significantly, the political transition in South Africa has seen a shift from a system of parliamentary supremacy to one of constitutional democracy. These were legal tectonic shifts affecting all branches of government, including the judiciary. These changes required a fundamental rethinking and restructuring, especially regarding the demographic make-up of the judges, judicial processes, judicial interpretation, judicial training, judicial appointments, and judicial tenure. These proposed shifts were comprehensively included and outlined in the constitution in a section devoted to the judicial system.

After the establishment of the first democratic system of government in South Africa in 1994, the judicial system was substantially overhauled, including the creation of a Constitutional Court. As the chart at the end of this chapter shows, at the apex of the court structure is the Constitutional Court as the final court of appeal. The Constitutional Court is solely mandated to decide disputes between organs of state and review the constitutionality of amendments to the constitution as well as provincial constitutions and legislation passed by all levels of government. Below the Constitutional Court sits a range of lower courts, some replicating the court structure under apartheid, albeit with a name change. The apex court under apartheid, the Appellate Division, was renamed the Supreme Court of Appeal. The Supreme Courts were renamed High Courts, and below them were the Magistrates' Courts. New courts were especially created to accommodate this transformative vision of the constitution, including the Land Claims Courts, the Equality Courts, the Electoral Court, and the Sexual Offences Courts. In addition, a nod to the emerging globally integrated economy at the end of apartheid was the establishment of the Competition Appeals Court and the Tax Court.

The constitution mandated a reimagining of the legal system to be more representative, accountable, accessible, and capable of providing justice to all South Africans irrespective of race, gender, and ethnicity. The appointment of judges was seen to be reflective of these values in their make-up, demographics, commitment, and philosophy. The issue of diversity and equity in the judiciary cannot seriously be confronted without addressing the context of ubiquitous patriarchy and sexism in South Africa-and especially within the legal profession. As I have argued elsewhere (Andrews, 2008), the legal profession in South Africa has always been dominated by white males, has generated a peculiarly masculinist culture, and is therefore not amenable to attracting huge numbers of female practitioners. ${ }^{5}$

I have also written elsewhere about the deeply patriarchal and masculinist cultural attitudes and odious sexist practices that still pervade South Africa despite a Bill of Rights that is unequivocally committed to the principle of equality (Andrews, 1998, 2001). Moreover, South African society evinces one of the highest statistics in the world regarding violence against women. ${ }^{6}$ The appointment of women judges, therefore, has to be examined within the context of a constitutional commitment to gender equality, on the one hand, and on the other hand, countervailing persistent negative attitudes and stereotypes of women, which prove very resistant to transformation. 
As a legacy of the British legal system, the profession is divided between advocates (barristers) and attorneys (solicitors), with only advocates mandated to appear before the higher courts in the country and attorneys relegated to practice in the lower Magistrates' Courts. ${ }^{7}$ Before 1994, admission as an advocate required an undergraduate and a law degree with passage in the then official languages, English and Afrikaans, as well as a course in Latin. Those admitted as attorneys required only an undergraduate law degree. It is not a stretch to imagine that overcoming these stringent academic requirements was a significant obstacle for black South Africans (for whom English and Afrikaans were second or third languages). In an adversarial system, and with only advocates traditionally having the right of appearance in the higher courts, advocates have historically attracted among their ranks individuals, overwhelmingly male, who are more predisposed to trial work. This is so for many reasons, including a greater sense of confidence that white males experience in a racially hierarchical society, more contacts with attorneys who may brief them, and the ability to work the long and erratic hours that trials sometimes require. These factors have resulted in fewer women practicing as advocates. ${ }^{8}$ Since the pool of judges has historically come from the ranks of advocates, who are seen as having relevant trial experience, this has therefore resulted in a limited pool of women available for appointment to the bench.

Because the transformation of the judiciary is mandated in the constitution, the situation has changed in South Africa, and judges are no longer chosen only from the ranks of advocates. As mentioned earlier, the numbers of women, especially black women, practicing as advocates was minimal in 1994-and to effect transformation, candidates from the ranks of attorneys (and to a lesser extent, academics and the civil service), had to be considered for appointment to the bench. In addition, the Legal Practice Act in South Africa, which was adopted in 2014 and came into force in late 2018, intends, among others, to streamline and regulate the legal profession and remove the traditional barriers between advocates and attorneys. The Act is clear about its intended goals, stating that it aims

[t]o provide a legislative framework for the transformation and restructuring of the legal profession in line with constitutional imperatives so as to facilitate and enhance an independent legal profession that broadly reflects the diversity and demographics of the Republic. ${ }^{9}$

This development is a significant one and should go some way toward removing some of the obstacles that women judges, especially black women judges, have experienced in gaining access to judicial appointments. However, since the provision has been in effect for less than two years, it is hard to evaluate its overall impact at this stage.

\section{Judicial diversity}

In South Africa, the issue of judicial diversity, and especially the appointment of female judges, is unique in two respects. The first is that the appointment of 
female judges emerged as part of the entire project of transformative constitutionalism, the purpose of which was to upend apartheid laws and policies in all their manifestations as well as to facilitate a fundamental shift in the unequal social, political, and economic relations that prevail in South Africa. Their historical exclusion from the bench and therefore, the absence of their perspectives meant that appointing female judges fell squarely within the project of transformative constitutionalism. In other words, new perspectives were brought into the process of adjudication.

The second unique aspect regarding judicial diversity in South Africa is that built into the project of constitutionalism is the idea that the jurisprudence itself would be transformative and therefore feminist. ${ }^{10}$ In other words, the South African constitution and Bill of Rights is designed to achieve certain ends, including racial justice, gender equality, and a broad range of social justice and human rights goals. The Preamble to the constitution states the need to "establish a society based on democratic values, social justice and fundamental human rights" and to "improve the quality of life of all citizens and free the potential of each person."11

Therefore, the constitutional imperative or mandate for all South African judges is a commitment to eradicating or minimizing the systemic inequality, repression, and subjugation that were the defining features of the apartheid legal order-and it is against this backdrop that the impact of female judges is to be evaluated. At least as a formal proposition, the judges had to be feminist in their jurisprudence ${ }^{12}$ - and the following discussion on the constitutional jurisprudence of the Constitutional Court in fact demonstrates such a commitment on the part of the overwhelming number of judges. Justice Sachs has noted that

certainly, all the judges on the Constitutional Court recognized the need for major transformations in society, not only the ugliness and unfairness and injustice of apartheid dreadfulness, but the fact that it had left quite deeply entrenched patterns of inequality and disparity. ${ }^{13}$

But the apparent ubiquity of the transformative constitutional vision does not render the issue of whether female judges make a difference an irrelevant or even a moot question. My point here is that following the establishment of the Constitutional Court in the wake of democracy in South Africa, a philosophical litmus test for its founding judges was introduced. They were handpicked and appointed to be the standard bearers for this new transformative jurisprudence. The selection of the first set of Constitutional Court judges was also symbolic, with all the judges having a pedigree of anti-apartheid credentials, including the first President of the court, a noted public interest lawyer. As noted by Justice Kriegler, one of the first judges appointed to the Constitutional Court by President Mandela, "the court has been painfully aware of its role as a constitutional trailblazer," signaling to South Africa and the world the radical jurisprudential shift from apartheid to democracy. ${ }^{14}$ 
As the terms of office of the initial cohort of judges come to an end (because of term limits), as the constitutional and other courts evolve, and as the commitment to transformation becomes more contested, it is not a given that those individuals who are appointed as judges will show the same heightened appreciation of gender equality as their female counterparts. Indeed, it is arguable that the decade-long incumbency of President Jacob Zuma, who was charged and acquitted of rape, has set back the formal commitment to gender equality (Gqola, 2015).

\section{Appointment of female judges}

In the dying days of apartheid, except for a black male and two females, the judiciary was comprised entirely of white men. In its final report, the Truth and Reconciliation Commission recommended that imbalances in the racial and gender composition of judges be urgently addressed and a fast-track judicial training program be introduced for black and women advocates, attorneys, or academics who aspire to judicial appointment. ${ }^{15}$ The drafters of South Africa's first post-apartheid constitution, in keeping with the principles of transparency and accountability, completely revamped the system of appointing judges. Under the apartheid system, the appointment of judges had been at the discretion of the President on the recommendation of the Minister of Justice, without formal input from the judiciary, the legal profession, or members of civil society-and certainly without public scrutiny (Dugard, 1978).

The Judicial Services Commission (JSC), comprising membership of the judiciary, government, the legal profession, and civil society, is empowered under the constitution to make recommendations to the President on the appointment of judges-after screening and interviewing "any appropriately qualified woman or man who is a fit and proper person" (as stated in the constitution). A transparent public process, with great scrutiny from the media and civil society organizations, the JSC was initially seen as a step toward greater transparency and inclusivity and a break from the secretive and exclusive approach adopted by prior apartheid and colonial administrations (Albertyn \& Bonthuys, 2016). And with the constitutional imperative that the judiciary reflect the South African racial and gender demographics, the appointments process is vital to achieving the goal of gender inclusivity and diversity.

Since 1994, the racial and gender make-up of the South African judiciary has been dramatically altered. In 1994, South Africa's 200 judges were overwhelmingly white and male, including only 2 black and 2 female judges. In 2018, the number of female judges has increased, and women now make up one-third of the judiciary. The Judge-President of the Supreme Court of Appeal, the second highest court, is female, and the acting head of the Land Claims Court is a woman. The Constitutional Court, however, has failed to appoint more than three females at any given time-and that court is still overwhelmingly male (Baines, 2017). Overall, the number of female judges, who make up only $36 \%$ of the judiciary, falls far short of the goal of a diverse and representative judiciary. This is in contrast to the racial transformation of the judiciary, where in 2017 it 
was recorded that white judges comprise only $34 \%$ of the judiciary. The judiciary has been transformed from being overwhelmingly white and male in 1994 to being overwhelming black and male today. ${ }^{16}$

Several reasons account for this deficit, including the legacy of apartheid and its exclusion of black women, the career paths in law that women choose (which may not always be congruent with judicial ambitions), the lack of support for women with judicial aspirations as well as confidence among women lawyers to make themselves available for judicial appointments, and the work-life balance and other issues that women, and indeed all professionals, constantly have to juggle. All these reasons are located in the rampant sexist and patriarchal attitudes that pervade South African society, including in the legal profession as well as the judicial appointment processes. The last factor, namely the judicial appointments process, has been a serious obstacle to the goals of gender equality in the judiciary. ${ }^{17}$

The JSC has shown a lack of commitment to appointing women judges and has on occasion demonstrated outright hostility to qualified female candidates during the JSC hearings. For example, in April 2019, a highly respected female judge was described as "overbearing" during her JSC interview..$^{18}$ When I was interviewed by the JSC for an appointment to the Constitutional Court in 2005, one JSC member pondered aloud whether "a boyfriend" would encourage my return to South Africa. Another female candidate for promotion to Deputy Judge-President, who is openly gay, was asked whether her gay lifestyle might not make her colleagues uncomfortable. ${ }^{19}$ What was alarming about this exchangevisible to the public - was that despite the fact that the questions raised were inappropriate and also unconstitutional (at least regarding the lifestyle of the gay judge), not one member of the JSC, including the Chief Justice, intervened to stop such a line of questioning. That room mirrored the attitudes prevalent in the wider South African society. Only a fundamental rethink of the make-up, operation, and processes of the JSC, with the stated goals of gender equality, will satisfy the constitutional mandate of inclusivity and equality in the judiciary (Johnson, 2014; Malleson, 1999).

\section{Jurisprudence on equality}

In this section, I explore the question of the difference that women judges make and what impact women judges have on constitutional jurisprudence with respect to gender equality.

As mentioned earlier in this chapter, the constitution sets out a particularized transformative vision of rights, a hegemonic interpretive endeavor embedded within a tacit societal agreement as to specific outcomes (Johnson, 2014). Part of that vision and purported outcomes relates to the capability and commitment of those who will review and adjudicate those rights. In short, who are the most appropriate judges to bring about the transformative outcomes? It may be worth noting a few unique features of South African constitutionalism to demonstrate its transformative potential, particularly regarding gender equality, as Karl Klare and others have 
noted (Klare, 1998; Johnson, 2014; Moseneke, 2002). The first is the horizontal and vertical nature of the constitution, applying to relationships between the state and citizens as well as to relationships between citizen and citizen. This approach to constitutionalism recognizes that discrimination is often shielded by and embedded in private as well as public relationships (McKinnon, 2012). The drafters of the constitution recognized that constitutional interpretation occurs within a universe of structural disadvantage, subordination, and discrimination, which are embedded in South Africa's political, economic, social, and legal system. The imperative is for courts, in their interpretation of the constitution, to derogate from the status quo to redress these structural impediments to equality (Liebenberg, 2005).

The constitution provides not just for a range of negative proscriptions on government conduct but also for a range of positive actions that need to be taken to address the unequal social and economic realities of South Africa. Therefore, a range of social and economic rights are made as fully justiciable as political and civil rights (Wilson \& Dugard, 2011; Liebenberg, 2005). The constitution also mandates that courts must consider international law and may consider foreign law in their deliberations, thereby creating the discursive space for jurisprudential innovation and creativity alongside global and comparative developments (Andrews, 2008).

The jurisprudence of the Constitutional Court suggests a clear break from the apartheid legal past to one forged on principles of dignity, equality, and nondiscrimination, with the goal of eradicating the legacies of subordination and discrimination against members of previously disadvantaged communities, including women. Women judges have, in their judgments, conscripted and interpreted the constitution to highlight and guarantee its transformative potential and possibilities. The judgments of the Constitutional Court, particularly in the first decade of its operation, elucidate a rich and compelling jurisprudence that has been heralded by constitutional and human rights scholars globally (Kende, 2009). The cases discussed later demonstrate a thoughtful articulation by the justices, especially the female justices, of the Constitutional Court for the need to eradicate the vestiges of discrimination against women.

On the issue of gender equality, the Court has for the most part articulated a comprehensive approach to equality, eschewing narrow formalistic approaches in favor of methodologies that adopt a more substantive version. Particularly in the first decade of the Court, the judges consistently underscored the primacy of equality as a foundational constitutional value. This approach has been accentuated in a range of early cases, including those involving the workplace rights of HIV-positive persons not to be discriminated against; ${ }^{20}$ the right of prisoners to vote $;{ }^{21}$ the rights of unmarried fathers in relation to adoption of their children; $; 2$ the employment rights of permanent residents not to be treated unfairly in comparison to citizens; ${ }^{23}$ the rights of homosexuals to engage in consensual sexual conduct; ${ }^{24}$ and the rights of African girls and women not to be discriminated against under Indigenous customary law. ${ }^{25}$

In one of its most notable early decisions and emblematic of its jurisprudential trajectory on equality, the Constitutional Court considered the constitutionality 
of an executive order signed by President Nelson Mandela. ${ }^{26}$ The President had sought to pardon "all mothers in prison on 10 May 1994, with minor children under the age of 12 years." In a gender equality challenge by a male prisoner, the Constitutional Court first considered the nature of the power granted to the President to pardon individuals or groups and concluded that the presidential power to pardon is guided by the principle of equality as articulated in the constitution.

In a lengthy multi-authored opinion, the court first found that the presidential pardon discriminated against the complainant, which triggered the presumption of unfairness and shifting the burden to the President to establish that the discrimination was fair. The court turned to an examination of the rationale that motivated the pardon in allowing the special remission for mothers of minor children. With empirical evidence from social welfare, psychiatric, and other experts to highlight the distinctive role that mothers play in the rearing of their children, the court highlighted the contradiction between the constitutional dictate that everyone be treated equally and the contextual reality that mothers bear the greatest burden of childrearing.

The majority noted that it could not be blind to the contemporary reality in South Africa, namely, the idealized situation in which fathers and mothers equally share childrearing tasks and the reality of the unequal burden of childrearing borne by mothers. The court noted that historically, stereotypes about women bearing the greater responsibility of childrearing were used to discriminate against women, whereas this stereotype was justified, since it resulted not in a burden to women but in an opportunity. Moreover, children would benefit substantially from the presidential pardon.

The Constitutional Court also considered what the likely outcome would be if equal treatment were applied, namely, the release of all prisoners, male and female, with children under the age of 12 . It concluded that no public benefit would be gained by releasing fathers, because they were not the primary caretakers of children. Noting that the Presidential Act provides for the individual application for remission of sentences by male prisoners where special circumstances can be shown, the court therefore found the discrimination to be fair. The dissent took issue with the rationale that women were the primary caregivers of young children, stating that this generalization was "a root cause of women's inequality" and that the rationale for majority decision would operate as a "detriment to all South African women who must continue to labor under the social view that their place is in the home."

As one of the two female justices on the Court, Justice O'Regan's concurring opinion is particularly noteworthy. She noted that the determination of whether the discrimination was unfair required a recognition that the ultimate constitutional goal is equal treatment, but that "equal treatment in circumstances of established inequality may well result in the entrenchment of that inequality." Justice O'Regan observed that despite the primacy of equality in the constitution, the factual reality in South Africa was that women did carry, and would continue to carry in the foreseeable future, the greater burden of childrearing. 
She considered this a crucial fact in looking at discrimination and determining the unfairness of the distinction made. Referring to the dissent's proposition that there would be a profound disadvantage for women in perpetuating the stereotype through the distinction, Justice O'Regan pointed out that the profound disadvantage did not result from the presidential pardon but from the inequality that was part of the social fabric of South African society. She disagreed with the dissent that this presidential pardon harmed women.

Justice O'Regan and the majority exemplify the broad contours of equality that the Constitutional Court was prepared to embrace from the outset. The court was concerned not just with formal equality (equal treatment), which can at times lead to inequality, but also with substantive equality, which contextualizes the actual experiences and reality of women within the formal impediments to equality. In a similar vein, another early case on gender equality involved a challenge by an unmarried father to the provisions of the Child Care Act, which allowed the adoption of children born out of wedlock without the consent of the father. ${ }^{27}$ For children born in wedlock, the consent of both parents was required. The father successfully challenged the law, and it was declared unconstitutional. Adopting a contextual approach reflecting the social reality of South Africa, the court, in a unanimous judgment, stated that a mother's "biological relationship with the child," nurtured during pregnancy and breastfeeding, is a special one. The court also noted that a mother gives "succor and support" to a child that is "very direct and not comparable to that of a father." In its analysis, the court surveyed several systems of marriage in South Africa, including some that were not formal, resulting in children being rendered illegitimate and disposing of the father's permission for adoption. For the court, the core issue was the relationship between the father and the child, and it found that the statute was too broad and therefore discriminatory in its blanket exclusion of the need for an unmarried father's permission for adoption of his child.

In 1996, the Constitutional Court considered another significant challenge to the equality provision in the constitution. ${ }^{28}$ It is in this case that we see the alternative perspectives that women judges bring, even when they are relegated to the dissent. A sex worker, along with the brothel owner, was charged under South Africa's Sexual Offences Act, which criminalizes sex for reward and brothel-keeping. The two charged brought a challenge to the constitutionality of the statute, claiming that it violated their right to human dignity, freedom of person, privacy, and economic activity. All the justices agreed that the prostitution provision does not infringe on the rights to human dignity and economic activity and that if it does limit the right to privacy, such limitation is justifiable. They also all agreed that the regulation of prostitution is primarily a matter for the legislature. An argument was made that the statute criminalizes the conduct of the sex worker but not the customer, and that targeting only the former was discriminatory based on gender. Disagreeing with this argument, the majority in the Constitutional Court upheld the law as gender neutral. They further held that in targeting the sex worker, the state is selecting an effective way to curb prostitution and that customers may be prosecuted under other criminal statutes. 
In her dissenting judgment (which she co-wrote with Justice Albie Sachs), Justice Kate O'Regan found the impugned provision discriminatory against women. Regarding the statute's designation of the prostitute as the "primary offender" and the customer as an accomplice, she noted that although the difference between a primary offender and an accomplice may have little impact as a matter of legality, the social stigma and impact is prejudicial to women and "runs along the fault lines of archetypal presuppositions about male and female behavior," thereby reinforcing gender inequality.

In addition, she also referred to the sexual double standards inherent in the distinction, observing that the discrimination in the distinction in the criminal statute has the "potential to impair the fundamental human dignity and personhood of women." Disagreeing with the majority that the stigma attaching to prostitutes arises not from the law but from social attitudes, she found the discrimination to be unfair. In her view, by primarily criminalizing the prostitute, the law reinforces and perpetuates sexual stereotypes, while it degrades the prostitute and the client escapes stigma. Justice O'Regan concluded that although the criminal statute appears, on the face of it, neutral, its substance undermines the value of the constitution and is therefore unconstitutional, violating a woman's right to dignity, equality, privacy, and freedom of the person. It is clear from the majority (male) judgment that issues of morality loomed large, positing the woman as someone making a choice to engage in immoral activity. For the dissenting justices, this was an issue of female subordination and outright discrimination. ${ }^{29}$

To further illustrate their different perspectives, in another case involving discrimination against a woman in a life partnership without a marriage contract, the two female justices gave a thoughtful dissenting judgment. ${ }^{30}$ The applicant here was in a cohabiting relationship for 16 years before the death of her partner. They chose not to get married. Her lawsuit emerged when she was denied a claim of maintenance against the estate of the deceased, since she was not deemed a "survivor" entitled to maintenance under the relevant statute. The lower court found the exclusion of permanent life partners from maintenance to be in violation of the constitutional right to equality and dignity, since the relationship seemed to all appearances akin to a marriage. On appeal to the Constitutional Court, the executor of the estate argued that the basis of the relevant statute was to protect surviving spouses who were married, not those who were in life partnerships. The majority of the court agreed with the executor, holding that the statute is intended to deal with the rights and obligations of marriage, especially in relation to maintenance payments. They held that the reciprocity regarding the duty of support between married people did not extend to unmarried couples. They believed that the discrimination was not unfair and that to expand the meaning of the statute to include life partners who were not married was to impose a duty upon death which did not exist during the lifetime of the deceased. In the words of the majority, such an imposition would be "incongruous, unfair, irrational and untenable."

The two female dissenting justices thought that the discrimination on the grounds of marital status was unfair. The justices noted that discrimination against cohabiting partners is not equal to racial or gender discrimination, but 
that such partners have suffered legal exclusion and are vulnerable members of society, especially regarding financial need. Many are subject to stigma and disapproval within society, even though such attitudes are on the wane. In the absence of comprehensive legal remedies that may ameliorate the situation of the surviving cohabitant upon the death of a partner, even where the relationship has been one of considerable length, she will be particularly vulnerable. The two dissenting justices acknowledged the importance of marriage as a social institution and in their decision, they explored the many ways that the law justifiably makes distinctions between married and unmarried persons. Emphasizing that the constitution prohibits unfair discrimination on the ground of marital status and that the discrimination cannot be justified, the justices noted that cohabiting relationships serve a similar social function to marriage.

It is notable that the two female justices of the court found the discrimination between married and unmarried couples unfair. To some extent, this case parallels the position of the majority in the prostitution case (mentioned earlier) where the male justices appear to be motivated by a sense of morality and a particular vision of a society, one that arguably is gendered. In contrast, the female judges are motivated by a sense of social justice, women's empowerment, and women's dignity.

\section{Do women judges make a difference?}

In this chapter, I have attempted to outline some of the challenges to attaining gender diversity in the judiciary in South Africa in line with the transformative vision of the constitution. I have also attempted to grapple with the question of whether female judges make a difference, especially regarding the outcome of cases. There are several factors to demonstrate that in fact, in South Africa, women judges have made and do make a difference. First, their historical exclusion on the basis of gender and also race ensures that female presence in the judiciary enables perspectives that were previously absent. (Cowan, 2006; Masengu, 2016). Indeed, many of the first wave of female judges, especially the female black judges, had grown up and been educated in the racist and authoritarian apartheid system, and many were activists against that system. ${ }^{31}$ Some were prominent public interest and human rights lawyers. Their perspectives were crucial in shaping the emerging constitutional jurisprudence, as witnessed, for example, in the development of substantive equality.

Second is the issue of representation, which goes to the core of the standing and credibility of the judiciary. The absence of female judges is not tolerable in a society committed to the constitutional goals of equality and dignity for all its citizens. In fact, as Ruth Cowan has shown in her film Courting Justice, by their very presence, they have added legitimacy to the judiciary (Cowan, 2006). Third, women judges are very important role models, and they create the real and imagined space for girls in South Africa to aspire to a judicial appointment. Women judges occupy previously held "men only" spaces, and their presence reinforces the normality of women in black robes as part of the judiciary, a characteristic that Dawuni refers to 
as the direct and indirect representative roles of women judges (Dawuni \& Bauer, 2016) Fourth, the presence of women judges may create a more inclusive courtroom space for lawyers, especially female lawyers (Kenney, 2013; Rackley, 2012). A former female Canadian Supreme Court Justice has observed that it is easier for women lawyers to appear as counsel before a woman judge, noting that the "difference is that the female judge is perceived as normal, with shared experiences and a shared reality that removes the need to 'translate' the submissions into 'man talk' or a context that a male judge will understand" (Wilson, 1990, at 518).

Fifth, women judges collaborating with their male judges in a visionary constitutional transformative project provides an important blueprint for other democracies. Just as the non-racial project in South Africa involves the support of whites, the project of gender equality requires males to demonstrate a fundamental commitment to the project. This is particularly crucial in South Africa, where the struggle for gender equality has been sorely tested, as noted by the alarming statistics on violence against women as well as the statistics on female poverty and employment equity. Finally, the presence of women judges in the room where deliberations are being conducted regarding the outcome of cases makes a difference (Peresie, 2005). Research has shown, for example, that the presence of female judges affects collegial decision-making and that in cases involving females as plaintiffs, male judges are more likely to be influenced by the perspectives of female judges (Choi, 2011).

\section{Conclusion}

The appointment of female judges in South Africa is part of the transformative project envisaged in the constitution. The presence of women in the judiciary is not merely symbolic but a substantive commitment to ensuring that the judiciary has credibility and legitimacy among the population and that the discrete experiences, competence, and legal skills of women are embraced to satisfy the constitutional mandate. Although limiting my examination to the female judges and jurisprudence of the Constitutional Court, I have pointed out that despite some overlap between the opinions of the female and male judges, the opinions of the female judges differ in some significant ways from their male counterparts. This difference is located in the distinct way that female judges have framed the legal issues, for example, formal versus substantive equality in the case of mothers, choice versus subordination in the case of unwed cohabitees, or morality versus subordination in the context of sex workers. The chapter has pointed out that considerable institutional obstacles continue to impede women's appointment to the judiciary, but once on the bench, they really make a difference.

\section{Notes}

1 This question implicitly revives the earlier sameness/difference debate among feminists. See Williams, J.C. (1991). Dissolving the sameness/difference debate: A postmodern path beyond essentialism in feminist and critical race theory. Duke Law 


\section{Penelope Andrews}

Journal, 296 and Scott, J.W. (1988). Deconstructing equality-versus-difference: Or, the uses of poststructuralist theory for feminism. Feminist Studies, 14, Spring 32. My intention here is not to revive that debate, since I am using the question here in the normative sense, namely, that women make a difference not because they bring perspectives based on their essential gendered characteristics but because of their lived experiences as women. As noted by Madam Justice Bertha Wilson of the Canadian Supreme Court, "If women lawyer and women judges through their differing perspectives on life can bring a new humanity to bear on the decision-making process, perhaps they will make a difference. Perhaps they will succeed in infusing the law with an understanding of what it means to be fully human," Wilson, B. (1990). Will women judges really make a difference? Osgoode Hall Law Journal, 28, 507, 522. Sally Kenney also explores this question in her research. Kenney, S.J. (2013). Gender and justice: Why women in the judiciary really matter (p.6). Routledge.

2 Cowan, R.B. Women's representation on the courts in the republic of South Africa. (2006). University of Maryland Law Journal of Race, Religion, Gender and Class, 6, 291, 304 (quoting female judges in South Africa reflecting on disrespectful and disparate treatment by their male counterparts).

3 Ibid., 302 (citing comments from Judge Howie in a lecture given in 2005).

4 Abella, R.S. (1987) The dynamic nature of equality. In S. Martin \& K. Mahoney (Eds) Equality and judicial neutrality (pp.8-9). Carswell, Toronto.

5 See Discussion Document on Gender Transformation in the Judiciary and the Legal Sector, Commission for Gender Equality (7/13/2018). Retrieved from https://www.justice.gov.z a/legislation/notices/2018/20180713-gg41766_gen394-CGE-GenderTransformation Judiciary.pdf

6 Report of the Special Rapporteur on Violence Against Women, its Causes and Consequences on her Mission to South Africa (2016). United Nations Human Rights Council.

7 In this chapter, I have not included a discussion of the Indigenous courts, which exist throughout the country to serve Indigenous communities in the implementation of customary law. As I have stated elsewhere, Indigenous law and Indigenous courts were always relegated to a secondary place in the racist colonial and apartheid structure. See Andrews, P.E. (2009).Who's afraid of polygamy? Exploring the boundaries of family, equality and custom in South Africa. 209 University of Utah Law Review, 2, 351. The seminal work on this subject has been the research of Martin Chanock. See Chanock, C. (2001). The making of South African legal culture 1902-1936: Fear, favour and prejudice. Cambridge.

8 Discussion Document on Gender Transformation in the Judiciary and the Legal Sector at Note $v$.

9 Legal Practice Act 28 of 2014.

10 Although the constitution does not use the term "feminist," I am suggesting that transformation and feminism are synonymous in this context, since feminism is committed to the project of the transformation of gendered structures, hierarchies, and relationships.

11 Constitution of The Republic of South Africa Act 1996. The human rights scholar, Makau Mutua, has noted: "The construction of the post-apartheid state represents the first deliberate and calculated effort in history to craft a human rights state-a polity that is primarily animated by human rights norms. South Africa was the first state to be reborn after the universal acceptance, at least rhetorically, of human rights ideals by states of all the major cultural and political traditions." Makau wa Mutua (1997). Hope and despair for a New South Africa: The limits of rights discourse. Harvard Human Rights Law Journal 10, 63, 65.

12 I am using the word "feminist" here in the same sense as I did earlier, namely, that the transformative vision of the constitution mandates a transformative approach. I use the term to analogize feminism with transformation-beyond formal gender 
equality. For example, in the following discussion of the Hugo case, I examine the Constitutional Court's elaboration of a substantive equality.

13 Assessment of the Impact of Decisions of the Constitutional Court and Supreme Court of Appeal on the Transformation of Society.(2017). Department of Justice and Constitutional Development. Retrieved from http://www.justice.gov.za/reportfiles/20 17-CJPreport-Nov2015-Final.pdf

14 Justice Johan Kriegler (2002). The Constitutional Court of South Africa. Cornell International Law Journal 36, 361, 364.

15 Report of the Truth and Reconciliation Commission, 5, 326. Retrieved from http://www .justice.gov.za/trc/report/finalreport/Volume5.pdf

16 Discussion Document on Gender Transformation in the Judiciary and the Legal Sector at Note 5.

17 Tilley, A. and Masengu, T. (2013). How the JSC fails gender test. Sunday Independent at: https://www.iol.co.za/sundayindependent/how-the-jsc-fails-gender-test-1503769

18 Rabkin, F. (2019). Constitutional Court interviews turn he-said-she-said. Weekly Mail and Guardian. Retrieved from https://mg.co.za/article/2019-04-05-00-constitutional-c ourt-interviews-turn-he-said-she-said/

19 Rickard, C. (2005). Judging women harshly. Sunday Times, October 23, 2005. Retrieved from https://allafrica.com/stories/200510240207.html

20 Hoffmann $v$ South African Airways 2001 (1) SA 1.

21 August and Another $v$ Electoral Commission and Others 1999 (3) SA 1 (CC).

22 Fraser v Naude Eु Another 1998 (11) BCLR 1357 (CC).

23 Larbi-Odam and Others v Member of the Executive Council for Education (North-West Province) and Another 1998 (1) SA 745 (CC).

24 National Coalition for Gay and Lesbian Equality and Others $v$ Minister of Home Affairs and Others 2000 (2) SA 1 (CC).

25 Bhe $\mathcal{E}$ Others $v$ Magistrate, Khayelitsha, $\mathcal{E}$ Others 2005 (1) SA 580 (CC).

26 President of the Republic of South Africa (and Another) v Hugo 1997 (4) SA 1.

27 Fraser $v$ Children's Court Pretoria North and Others 1997 (2) SA 261 (CC).

28 S v Jordan and Others 2002 (6) SA 642.

29 The other female justice, Justice Mokgoro, took no part in the deliberation. Justice O'Regan's dissent was joined by Justice Ackermann, Langa, and Goldstone.

30 Volks NO $v$ Robinson and Others 2005 (5) BCLR 446 (CC).

31 A perusal of the biographies of the female justices of the Constitutional Court highlights their involvement in the struggle against apartheid and for social justice. See https://www.concourt.org.za/index.php/judges/former-judges

\section{Bibliography}

Abella, R.S. (1987). The Dynamic Nature of Equality. In Martin, S. \& Mahoney, K. (Eds.), Equality and Judicial Neutrality, 3, 8-9. Carswell.

Albertyn, C., \& Bonthuys, E. (2016). South Africa: A Transformative Constitution and a Representative Judiciary. In Bauer, G. \& Dawuni, J. (Eds.), Gender and the Judiciary in Africa: From Obscurity to Parity? 49. Routledge.

Andrews, P. (2010). The Judiciary in South Africa: Independence or Illusion? In Dodek, A. \& Sossin, L. (Eds.), Judicial Independence in Context 466. Toronto, ON: Irwin Law.

Andrews, P. (2010). Without Fear, Favor or Prejudice: Judicial Transformation and the Independence of the Judiciary in South Africa. In: Cummings, S. (Ed.), Law and Social Movements 197. Routledge.

Andrews, P.E. (1998). Striking the Rock: Confronting Gender Equality in South Africa. Michigan Journal of Race and Law, 3, 307. 


\section{Penelope Andrews}

Andrews, P.E. (2001). The Step-Child of National Liberation: Women and Rights in the New South Africa. In Andrews, P.E. and Ellmann, S. (Eds.). The Post-Apartheid Constitutions: Reflections on South Africa's Basic Law 326. Ohio University Press.

Andrews, P.E. (2008). Incorporating International Human Rights Law in National Constitutions: The South African Experience. In: Bratspies, R. \& Miller, R. (Eds.), Progress in International Organizations 837. Martinus Nijhof.

Andrews, P.E. (2009). Who's Afraid of Polygamy? Exploring the Boundaries of Family, Equality and Custom in South Africa. University of Utah Law Review, 2, 351.

Baines, B. (2017). Women Judges on Constitutional Courts: Why Not Nine Women? In: Irving, H. (Ed.), Constitutions and Gender. Edward Elgar.

Banks, T.L. (2017). President Obama and the Supremes: Obama's Legacy: The Rise of Women's Voices on the Courts. Drake Law Review, 65, 912.

Bauer, G. and Dawuni, J. (Eds.) (2016). Gender and the Judiciary in Africa: From Obscurity to Parity? Routledge.

Chanock, M. (2001). The Making of South African Legal Culture 1902-1936: Fear, Favour and Prejudice. Cambridge University Press.

Choi, S.J. et al. (2011). Judging Women. Journal of Empirical Legal Studies, 8(3), 504.

Coontz, P. (2000). Gender and Judicial Decisions: Do Female Judges Decide Cases Differently than Male Judges? Gender Issues 18, 59.

Cowan, R. (2006). Women's Representation on the Courts in the Republic of South Africa. University of Maryland Law Journal of Race Religion Gender 6, 291.

Dawuni, J. (2016). To "Mother" or Not to "Mother": The Representative Roles of Women Judges in Ghana. Journal of African Law, 60, 419.

Dawuni, J. and Kuenyehia, A. (Eds.) (2018). International Courts and the African Woman Judge: Unveiled Narratives. Routledge.

Department of Justice and Constitutional Development, Assessment of the Impact of Decisions of the Constitutional Court and Supreme Court of Appeal on the Transformation of Society (2017). at: http://www.justice.gov.za/reportfiles/2017-CJPreport-Nov2015 -Final.pdf

Dixon, R. (2010). Female Justices, Feminism, and the Politics of Judicial Appointment: A Re-Examination. Yale Journal of Law and Feminism, 21, 297.

Dugard, J. (1978). Human Rights and the South African Legal Order. Princeton University Press.

Durojaye, E. and Olubayo, O. (2016). The African Commission on Human and People's Rights and the Woman Question. Feminist Legal Studies, 24, 315.

Former Judges, Constitutional Court at: https://www.concourt.org.za/index.php/judges/f ormer-judges

Gilligan, C. (1982). In A Different Voice: Psychological Theory and Women's Development. Harvard.

Gqola, P. (2015). Rape: A South African Nightmare. Jacana.

Graycar, R. (2008). Gender, Race, Bias and Perspective: Or, How Otherness Colours Your Judgment. International Journal of the Legal Profession, 15, 73.

Hunter, R. (2008). Can Feminist Judges Make a Difference? International Journal of the Legal Profession, 15, 7.

Hunter, R., McGlynn, C., \& Rackley, E. (Eds.) (2010). Feminist Judgements: From Theory to Practice. Hart.

Irving, I. (Ed.) (2017). Constitutions and Gender. Edward Elgar.

Johnson, R.E. (2014). Women as a Sign of the New: Appointments to South Africa's Constitutional Court Since 1994. Politics and Gender, 10(4), 595. 
Kende, M. (2009). Constitutional Rights in Two Worlds: South Africa and the United States. Cambridge University Press.

Kenney, S.J. (2013). Gender and Justice: Why Women in the Judiciary Really Matter. Routledge.

Klare, K. (1998). Legal Culture and Transformative Constitutionalism. South African Journal on Human Rights, 146-188.

Kriegler, J. (2002). The Constitutional Court of South Africa. Cornell International Law Journal, 36, 361.

Lack of Transformation of the Judiciary, Commission for Gender Equality (2016). at: https://ge nderjustice.org.za/publication/lack-gender-transformation-judiciary/

Li, M. et al. (2020). Who's Going to Law School? Trends in Law School Enrolment since the Great Recession. U.C. Davis Law Review 54. forthcoming at: file://C:/Users/penel/ Downloads/SSRN-id3559213.pdf

Liebenberg, S. (2005). Needs, Rights and Social Transformation: Adjudicating Social Rights. Center for Human Rights and Global Justice Working Paper, Economic and Social Rights Series 8.

Mackinnon, C.A. (2012). Gender in Constitutions. In: Rosenfeld, M. and Sajo, A. (Eds.). Oxford Handbook of Comparative Constitutional Law. Oxford University Press..

Malleson, K. (1999). Assessing the Performance of the Judicial Services Commission. South African Law Journal 116, 36.

Malleson, K. (2003). Justifying Gender Equality on the Bench: Why Difference Won't Do. Feminist Legal Studies, 11, 1.

Masengu, T. (2016). It's a Man's World: Barriers to Gender Transformation in the South African Judiciary. Perspectives from Women Advocates and Attorneys. International Journal of the Legal Profession, 23, 305-319.

Masengu, T. (2019). The Judicial Service Commission and the Appointment of Women: More to It than Meets the Eye. International Journal of the Legal Profession.

Mckinnon, C.A. (2011). Substantive Equality: A Perspective. Minnesota Law Review, 96, 1.

Moseneke, D. (2002). Transformative Adjudication. South African Journal of Human Rights, 18, 309.

Mossman, M.J. (2005). Defining Moments for Women as Lawyers: Reflections on Numerical Gender Equality. Canadian Journal of Women and the Law, 17, 15.

Mureinik, E. (1994). A Bridge to Where? Introducing the Interim Bill of Rights. South African Journal of Human Rights, 10, 31.

Mutua, M. (1997). Hope and Despair for a New South Africa: The Limits of Rights Discourse. Harvard Human Rights Law Journal, 10, 63.

Norgren, J. (2018). Stories from Trailblazing Women Lawyers: Lives in the Law. NYU Press.

Peresie, J.L. (2005). Female Judges Matter: Gender and Collegial Decisionmaking in the Federal Appellate Courts. Yale Law Journal, 114, 1759.

Phooko, M.R. and Radebe, S.B. (2016). Twenty-Three Years of Gender Transformation in the Constitutional Court of South Africa: Progress or Regression. Constitutional Court Review, 8, 306.

Rabkin, F. (2019). Constitutional Court Interviews Turn He-Said-She-Said. Weekly Mail and Guardian at: https://mg.co.za/article/2019-04-05-00-constitutional-court-inter views-turn-he-said-she-said/

Rackley, E. (2012). Why Feminist Legal Scholars Should Write Judgments: Reflections on the Feminist Judgments Project in England and Wales. Canadian Journal of Women and the Law, 24, 389. 
Report of the Special Rapporteur on Violence Against Women, Its Causes and Consequences on Her Mission to South Africa (2016). United Nations Human Rights Council.

Report of the Truth and Reconciliation Commission, Volume 5 at: http://www.justice.gov.za/ trc/report/finalreport/Volume5.pdf

Rickard, C. (2005). Judging Women Harshly. Sunday Times, October 23, 2005 at https:// allafrica.com/stories/200510240207.html

Schultz, U. and Shaw, G. (2003). Women in the World's Legal Profession. Hart Publishers.

Schultz, U. and Shaw, G. (eds.) (2013). Gender and Judging. Hart Publishers.

Scott, J.W. (1988). Deconstructing Equality-versus-Difference: Or, the Uses of Poststructuralist Theory for Feminism. Feminist Studies, 14(1) 32.

Stanchi, K.M., Berger, L.L. and Crawford, B.J., (Eds.) (2016). Feminist Judgments: Rewritten Opinions of the United States Supreme Court. Cambridge.

Tilley, A. and Masengu, T. (2013). How the JSC Fails Gender Test. Sunday Independent at: https://www.iol.co.za/sundayindependent/how-the-jsc-fails-gender-test-1503769

Williams, J.C. (1991). Dissolving the Sameness/Difference Debate: A Post-Modern Path Beyond Essentialism in Feminist and Critical Race Theory. Duke Law Journal, 1991, 296.

Wilson, B. (1990). Will Women Judges Really Make a Difference? Osgoode Hall Law Journal, 24, 507.

Wilson, S. and Dugard, J. (2011). Taking Poverty Seriously: The South African Constitutional Court and Socio-Economic Rights. Stellenbosch Law Review, 22, 664.

\section{Case law}

August and Another v Electoral Commission and Others [1999] 3 SA 1 (CC)

Bhe EO Others v Magistrate, Khayelitsha, EO Others [2005] 1 SA 580 (CC)

Fraser v Naude E Another [1998] 11 BCLR 1357 (CC)

Larbi-Odam and Others $v$ Member of the Executive Council for Education (North-West Province) and Another [1998] 1 SA 745 (CC)

National Coalition for Gay and Lesbian Equality and Others v Minister of Home Affairs and Others [2000] 2 SA 1 (CC)

President of the Republic of South Africa (and Another) v Hugo [1997] 4 SA 1 (CC)

$S v$ Jordan and Others [2002] 6 SA 642 (CC)

Volks NO $v$ Robinson and Others [2005] 5 BCLR 446 (CC).

\section{Legislation}

Constitution of the Republic of South Africa Act 1996

Legal Practice Act 28 of 2014 